\title{
Sentidos do fio: diálogos com as artistas Simone Moraes e Sonia Gomes
}

\author{
Senses of the Thread: Dialogues with the Artists \\ Simone Moraes and Sonia Gomes
}

\author{
Sentidos del hilo: diálogos con los artistas \\ Simone Moraes y Sonia Gomes
}

Mariana Guimarães (Universidade Federal do Rio de Janeiro, Brasil) * Evângelo Gasos (Universidade Veiga de Almeida, Brasil) **

https://doi.org/10.22409/poiesis.v22i37.45614

\begin{abstract}
RESUMO: O texto apresenta as transcrições das entrevistas realizadas com as artistas Simone Moraes e Sonia Gomes para o documentário Sentidos do fio, projeto de documentário que versa sobre as motivações e reflexões realizadas por artistas contemporâneos brasileiros cuja pesquisa tangencie a investigação com o fio como materialidade e conceito nesta arte. As entrevistas apresentam um panorama sobre as relações das artistas com o têxtil, a inserção das práticas, originariamente restritas aos espaços domésticos, no cenário da arte contemporânea, a desconstrução e o desfazimento dos usos e a expansão da linguagem.
\end{abstract}

PALAVRAS-CHAVE: fio; arte contemporânea e audiovisual

\footnotetext{
* Mariana Guimarães é artista, educadora, pesquisadora, docente de Artes Visuais no Colégio de Aplicação da UFRJ e doutoranda em Artes Visuais pelo PPGAV da EBA/UFRJ. Orcid: https://orcid.org/0000-0003-4009-3451. E-mail: marianasguimaraes@hotmail.com. ** Evângelo Gasos é mestre em Linguagens Visuais e docente nos cursos de Cinema e Comunicação Social da Universidade Veiga de Almeida. Orcid: https://orcid.org/0000-0002-6774-2004. E-mail: evangelogasos@gmail.com.
} 
ABSTRACT: This text presents the transcripts of the interviews conducted with the artists Simone Moraes and Sonia Gomes for the documentary Sentidos do fio, a project of one documentary about the motivations and reflections carried out by contemporary Brazilian artists whose research touches the investigation with thread as materiality and concept in this art. The interviews present an overview of the artists' relations with textiles, the insertion of practices, originally restricted to domestic spaces, in the contemporary art scene, the deconstruction and undoing of uses and expansion of language.

KEYWORDS: thread; contemporary art and audiovisual

RESUMEN: Transcripciones de las entrevistas realizadas con las artistas Simone Moraes y Sonia Gomes para el documental Sentidos do fio, un proyecto de una película documental sobre las motivaciones y reflexiones realizadas por artistas brasileños contemporáneos cuya investigación toca el alambre como materialidad y concepto en esta arte. Las entrevistas presentan un panorama de las relaciones de los artistas con los textiles, la inserción de prácticas, originalmente restringidas a los espacios domésticos, en la escena del arte contemporáneo, la deconstrucción y deshacer los usos y la expansión del lenguaje.

PALABRAS CLAVE: hilo; arte contemporánea y audiovisual

Recebido: 28/8/2020; Aprovado: 6/12/2020; Publicado: 2/1/2021.

Citação recomendada:

GUIMARÂES, Mariana; GASOS, Evângelo. Sentidos do fio: diálogos com as artistas Simone Moraes e Sonia Gomes. Revista Poiésis, Niterói, v. 22, n. 37, p. 245-263, jan./jun. 2021.

[https://doi.org/10.22409/poiesis.v22i37.45614]

(cc) BY-NC-ND Este documento é distribuído nos termos da licença Creative Commons Atribuição-NãoComercial 4.0 Internacional (CC-BY-NC) (c) 2021 M. Guimarães, E. Gasos

Mariana Guimarães; Evângelo Gasos, Sentidos do fio: diálogos com as artistas Simone Moraes e Sonia Gomes. 


\section{Sentidos do fio: diálogos com as artistas Simone Moraes e Sonia Gomes}

No desejo da investigação do fio como linguagem e potência, e pela instauração de um campo que busque compreendê-lo a partir de sua heterogeneidade, de suas dimensões plásticas e conceituais, de sua criação e recriação de novas histórias, aponta o Sentidos do Fio. O projeto do documentário procura caminhos para reflexões e experiências distintas com a linguagem através da construção de uma polifonia de saberes relacionados com diversos contextos, em que estão inseridos os artistas e suas pesquisas, de modo que a experiência com a linguagem deixe de estar relacionada apenas com o objeto em si e passe a se relacionar com as forças que compõem a linguagem, a memória, as conexões, as redes, os sentidos, os muitos sentidos do fio.
O projeto objetiva documentar vozes de artistas de diferentes gerações tecendo uma polifonia de experiências e pensamentos sobre o tema.

Aqui apresentamos um pequeno recorte do projeto, o das artistas Simone Moraes e Sonia Gomes, ambas entrevistadas pela artista Mariana Guimarães, na cidade de São Paulo em julho de 2019: Simone Moraes, em seu ateliê localizado no bairro de Pinheiros, e Sonia Gomes, na galeria Mendes Wood. Como proposta metodológica para a construção do roteiro, selecionamos duas perguntas comuns a todos os entrevistados: Como é o encontro de sua obra com o fio? Qual o sentido do fio? As demais perguntas estavam relacionadas com questões mais especificas da obra e pesquisa de cada artista. 
Nesta direção, as entrevistas realizadas com as artistas trazem um panorama sobre as relações das mesmas com os trabaIhos têxteis, a transmissão das práticas no contexto doméstico, historicamente destinadas à formação dos corpos e dos saberes femininos. A passagem e desconstrução dos usos e as relações com a arte contemporânea, o desenho, o texto, o pensamento filosófico e plástico sobre o fio, visto por ambas como materialidade e força, e ainda suas relações com a ancestralidade, a natureza e orgânico. Pesquisas e pensamentos que produzem uma ampliação e desfazimento nas fronteiras da linguagem, nas relações entre artesanato e arte, criando assim, novas possibilidades de reflexão, usos, pensamentos e abertura de novos caminhos, onde o fio conduz e sustenta a caminhada. E aponta para a construção de narrativas outras que ultrapassam limitações históricas, arraigadas em condutas limitantes e forjadas ao corpo feminino, enquanto possibilita a criação de novos territórios e cartografas. O fio torna-se uma potente ferramenta de transformação e de invenção de novas possibilidades de existência, de de criação e pesquisa na obra de Simone Moraes e Sonia Gomes.
Entendemos que essas entrevistas podem contribuir para a pesquisa e a historiografia da arte no Brasil com a documentação de processos e práticas que dialoguem em torno de um tema, disponibilizando, através da produção audiovisual, o acesso democrático ao material coletado para pesquisadores e artistas, diante da carência de pesquisa e de documentação sobre o fio na arte contemporânea brasileira, ao que se soma o crescente interesse e produção de pesquisas e obras.

Através de uma parceria interinstitucional entre a Universidade Federal do Rio de Janeiro e a Universidade Veiga de Almeida, com o diálogo entre os projetos de pesquisa Arte do Fio (CAp-UFRJ ) e o projeto Criativa Imagem Web (UVA) - coordenado por Evângelo Gasos, que também dirigiu as gravações do documentário -, foi possível a realização da primeira etapa de produção e gravação das entrevistas com 27 artistas no Rio de Janeiro e em São Paulo. 


\section{Simone Moraes}

Mariana Guimarães: Simone querida, conte um pouco do encontro do seu trabalho com o fio. Como se deu esse processo?

Simone Moraes: Então, o fio faz parte do meu trabalho faz muito tempo. Acredito que desde quando comecei a desenhar, muito tempo atrás. Eu não tinha, porém, muito esse olhar para o fio. Fazia os desenhos, sempre anotei em caderninhos por onde eu andava; pelo fato de me deslocar, o caderninho era mais prático e sempre fez parte dos desenhos. Não entendia muito por que eu fazia tantos desenhos, só daí comecei a entender um pouco mais esse processo. Foi muito orgânico, pois acontecia e eu fazia porque tinha de fazer. Então comecei a entender que queria fazer esse desenho para poder deixar meu gesto, deixar meu registro. Emprestava meu corpo para fazer esse registro. Quando comecei a ter noção de que emprestava meu corpo para fazer esse desenho, comecei também a fazer uma pesquisa do meu corpo perante a natureza e o desenho. Então aparece nitidamente esse fio, e em algumas ações eu materializo esse fio. Às vezes no grafite ou no bidimensional não fica tão claro, aí começo a usar o fio para demarcar esse desenho, mas é um desenho como um rastro desse corpo, como um rastro do meu gesto. São algumas ações como o nó, o nó surgiu justamente de pensar esse desenho. Comecei a pensar esse meu deslocamento e como a gente faz uma linha imaginária e aí pensei "e se eu tivesse realmente essa linha?" $\mathrm{Na}$ ação Nó, escolhi a corda de sisal por ser um elemento natural, e literalmente faço esse desenho em um quarteirão de uma instituição pensando muito em quem se adentra nessa demarcação: se são as pessoas do entorno ou não. A pensar nesse gesto, nesse pensar registro o floema, em que tramo essas lãs pensando em como o traço do meu corpo deixa o rastro no chão da instituição e, então, as pessoas podem pisar pensando justamente nesse contato no outro, com esse fio ou com essa linha. $\mathrm{Na}$ verdade, esse fazer artístico do fio aparece no corpo fazendo o desenho, mas também aparece no outro com o meu processo. É muito importante o outro no meu processo.

Mariana Guimarães: Você vai fazendo uma expansão do fio, não é? Percebo que ele vai se deslocando do suporte. Aí você vai 
se libertando mesmo, quase que uma liberação da linha desse suporte e desse fio também como um suporte tradicional do tecido ou mesmo da utilização de um instrumento, como as agulhas. E você ganha esse espaço como um fio expandido, é quase que um bordado expandido ou um tricô expandido que rompe a dimensão do suporte.

Simone Moraes: Sim, ele rompe a dimensão do suporte e vai ganhando espaço; então, cada trabalho é um novo. Porque os espaços são diferentes e vejo também como meu corpo se comporta naquele espaço. Essa feitura do tempo que vai passando está muito registrada no meu trabalho; assim como o tempo vai pesando esse corpo. Começo em um ritmo e quando viro o último novelo, depois de dias tecendo, meu corpo está muito lento, está muito pesado, pensando nesse fio como pele. Esse fio vai se aglomerando nesse meu corpo e começa a pesar. Então, quando viro o último pontinho, já estou exausta dessa repetição da mesma forma e do mesmo ponto.
Mariana Guimarães: E da mesma forma na performance Nó, tem um desprendimento e um uso da força.

Simone Moraes: Isso, pensando justamente nesse corpo que é emprestado para fazer o desenho. O fio mostra o invisível, pois eu fiz um tempo atrás uma residência na fazenda São João e lá vi um vale muito bonito e quis fazer um desenho dele. Então levei um aparelho de escutar o silêncio e um aparelho de som onde esse eco, essa onda é o fio dizendo o que a pessoa vai fazer perante o corpo e a natureza do vale. Então esse fio muitas vezes não é algo materializado: é invisível. $E$ sempre está presente nos meus trabalhos. Mariana Guimarães: Um fio que conecta, não é? Tem uma relação que considero bastante interessante no teu trabalho do fio, que ultrapassa a tecnologia manual, ou sofisticada, como a que hoje está nas redes digitais. Percebo uma relação muito próxima com o fio orgânico e queria que você comentasse um pouco dessa relação do que seria o fio orgânico e sua pesquisa, para saber como ela atravessa esse assunto. 


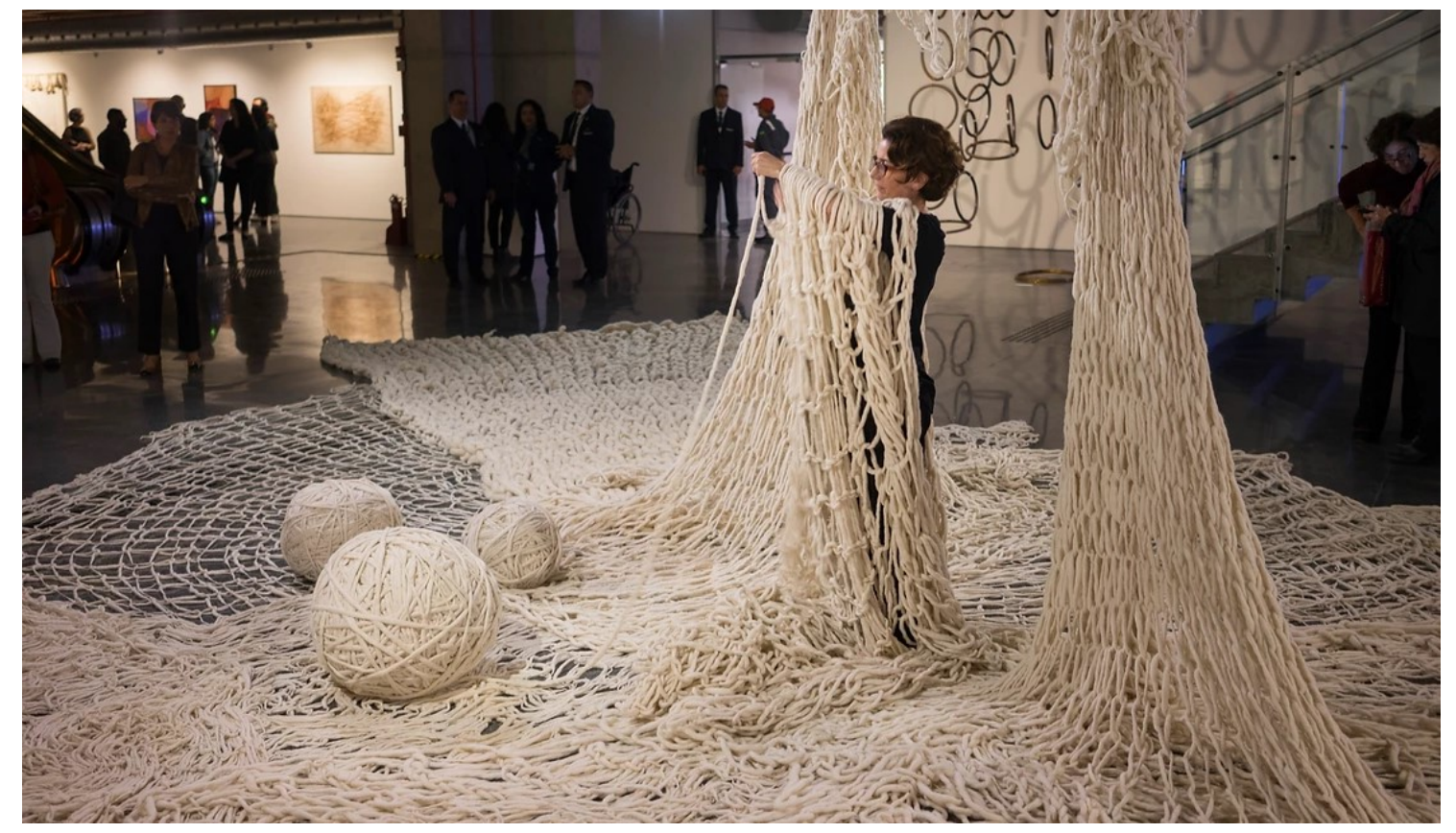

Fig. 1 - Simone Moraes, Floema, 2017.

Registros da ação, 2019, BNDES, Exposição Da linha, o fio.

(Fonte: https://www.simonemoraes.net/floema1) 
Simone Moraes: Sempre morei em área rural e esse contato com a natureza me proporciona essa conexão com esse fio orgânico. Então me interessam muito os materiais naturais e a paisagem. Ela nos conecta com esse fio. Esse corpo em contato com a paisagem maior. E esses elementos naturais me interessam muito. Nessa pesquisa que venho fazendo, sempre coleto elementos naturais e, através deles, existe esse contato com o fio, com o fio orgânico. Isso é muito nítido porque essas formas de células orgânicas que vão se alastrando acontecem no desenho bidimensional desse fazer; da mesma forma que se alastram e vão formando outras formas, mas também acontecem nas ações que faço na natureza. E muitas vezes é daquele contato, único ali. Às vezes não programo fazer essa ação. O Florilégio é uma ação em que chego em uma casa na área rural e tem uma paineira que todo ano floresce. Nesse dia em especial, o chão estava forrado com essas flores e com as flores caindo a cada minuto. Deu uma vontade muito grande de costurar essas flores e voltar essas flores para a árvore: então, desse fio, fiz um pendão florilégio, com as flores que já estavam caídas e as que estavam caindo. Minha proposta era pegar aquela que caía naquele minuto, a viva e não tão seca. Esse fio acontece de uma maneira orgânica, de uma maneira fluída.

Mariana Guimarães: O seu trabalho tem essa bela dimensão, não é? Percebo também que você não faz uma coleta, você faz uma colheita. Quando a gente faz uma colheita é diferente da coleta e vou percebendo nessa sua colheita um fio invisível, mas que marca como se fossem linhas cartográficas; então você vai cartografando e criando essas linhas e relações com o meio do seu trabalho do azul; a paineira... gostaria que você falasse um pouco dessa linha cartográfica, desse fio cartográfico que vai produzindo sua pesquisa.

Simone Moraes: Então, essa colheita que você fala existe muito antes de eu virar artista. Penso que eu faço essa coleta querendo entender um pouco a existência ou "por que estou naquele lugar?" Na infância fui uma pessoa que vivia em um lugar só. Na mesma casa, no mesmo lugar e, depois que me casei, passei a me deslocar muito. Nesse fio invisível quero coletar um pedacinho da cada lugar em que estive, para entender o lugar e entender aquele universo

Mariana Guimarães; Evângelo Gasos, Sentidos do fio: diálogos com as artistas Simone Moraes e Sonia Gomes. 
das relações com as pessoas. Tenho pensado muito e pensando em ficar mais próxima desses objetos que vou coletando. Como as terras, onde vou, pego um pouquinho de terra e vou formando uma paleta de cores bem diferente. É como se trouxesse o lugar aqui para o meu ateliê. Com os espinhos coletados no Cerrado, faço um desenho, mas pensando em entender mesmo a natureza e qual é o nosso papel diante dela e do universo. Coleto pedras, terra, flores, sementes... Semente para mim é algo que venho coletando há muito tempo e acho magnífico pensar que vai virar uma plantinha, uma árvore, que vai dar frutos. Então também coleto folhas e o fio sempre está presente na conexão desses elementos naturais, bichinhos também, como borboletas.

Mariana Guimarães: Há uma relação presente em muitos artistas, muito tênue, entre a linha escrita, a linha desenhada e o fio tecido. E o mesmo acontece com a questão da literatura que aparece muito no seu trabalho; há livros, há um texto que está sempre te fundamentando e te norteando como nesses trabalhos com o livro. Quando você fala desse seu capturar, fico quase pensando em um chapeuzinho vermelho às avessas. Ela deixa o pãozinho para não se perder e vai recolhendo para se encontrar.

Simone Moraes: Para me encontrar e para me encontrar com o outro. Encontrar o outro para mim é muito importante. É o meu trabalho e tem realmente essa conexão com o fazer do outro e com a escuta do outro; dessa maneira eu me encontro. E como você falou da escrita, ela, o bordado e o desenho para mim são a mesma coisa. No trabalho em que venho desenvolvendo já há alguns anos, que é o meu enxoval junto com a Carol, minha filha. Essa conexão das mulheres que passaram por aquele enxoval, minha bisavó, minha avó e minha mãe que herdaram e que passaram esse enxoval para mim. E a escrita com que me deparei, uma carta da minha tataravó para minha bisavó onde ela escreve uma carta quando faz 10 anos, falando que precisaria ser uma menina obediente para ser digna de receber os elogios. Essa carta e esse enxoval eu ressignifico com um diálogo com a Carol e com essas mulheres que passaram e fizeram esse enxoval. Então a escrita, o bordado e o desenho para mim são a mesma coisa. 


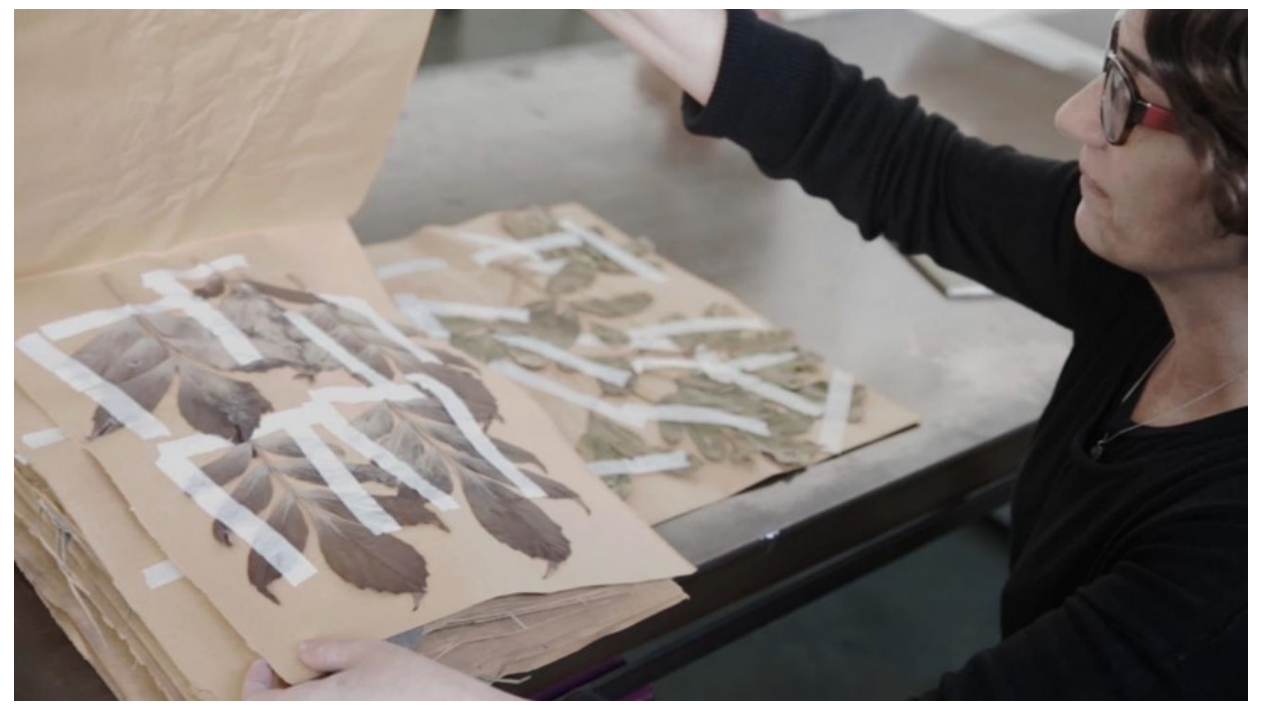

Fig. 2 - Simone Moraes. Frame retirado do filme Sentidos do Fio. (Fotografia de Juno e Patrícia Araújo) 
Mariana Guimarães: Qual o sentido do fio para você?

Simone Moraes: O fio segura o universo com sua teia cósmica. Embala a vida nos casulos e placentas. Conecta sentimentos, liga gerações. O fio constrói e desconstrói. O fio é linha. Linha do tempo, do horizonte. Linha que contorna as linhas das mãos que tecem. Tecem o fio com o corpo e com o outro. O fio brota. O fio é vida.

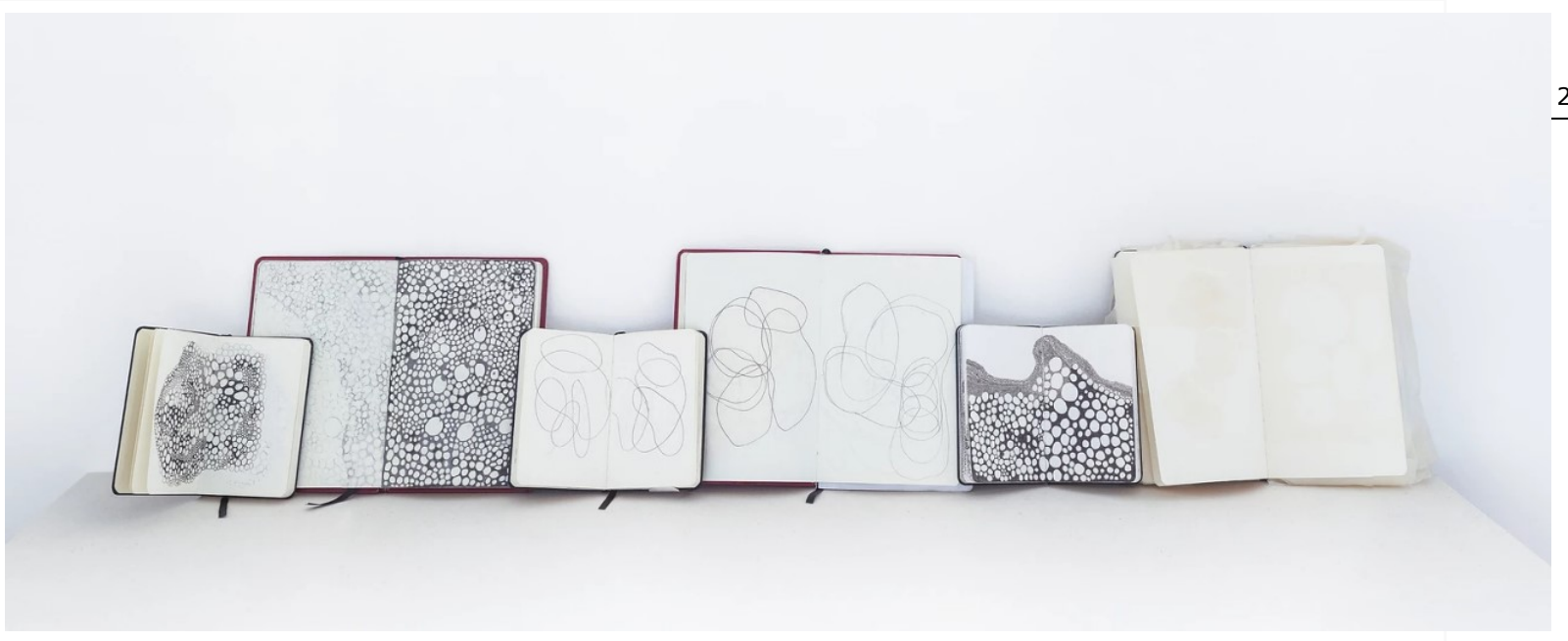

Fig. 3 - Simone Moraes, Cadernos, 2014. nanquim, grafite e colagem sobre papel, dimensões variáveis. (Fonte: https://www.simonemoraes. net/cadernos) 


\section{Sonia Gomes}

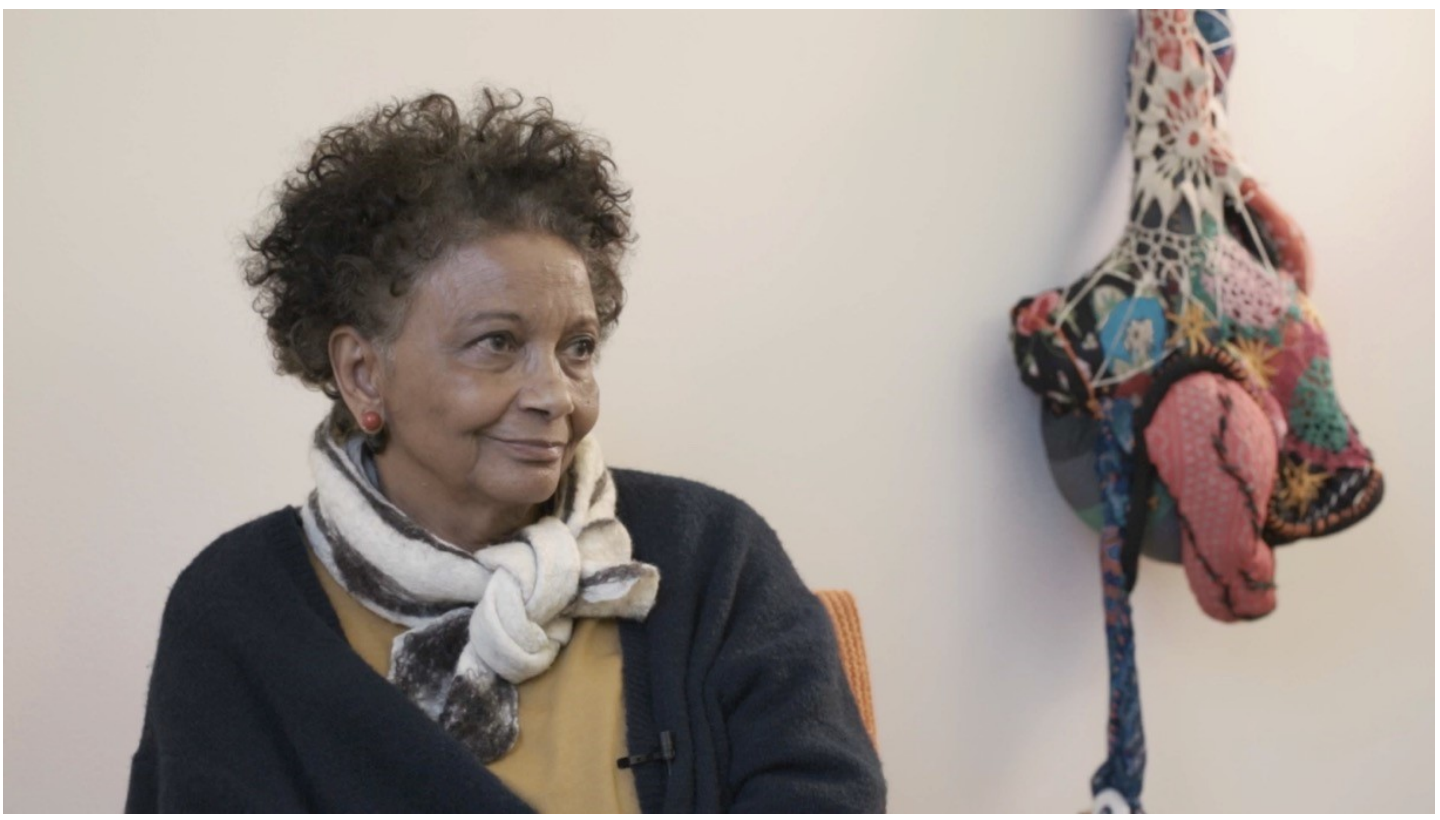

Fig. 4 - Frame retirado do filme Sentidos do Fio. Fotografia de Juno e Patricia Araujo. 
Mariana Guimarães: Sonia querida, agradeço muito pela presença, uma alegria. Como é o encontro do seu trabalho, da sua pesquisa com o fio? Como aconteceu?

Sonia Gomes: Sou negra e trabalho com arte, meu trabalho é super artesanal, quando comecei a trabalhar, o entendimento era que a pessoa negra não fazia arte, mas sim artesanato.

Então não podia ser uma artista, não é? Eu era uma artesã. Então meu trabalho foi levado para essa categoria de artesanato. Aí eu só respondia: pode me levar para onde quiser, não me interessa rótulo; é isso que sei fazer, vou continuar fazendo; isso que é minha verdade, não me interessa se é arte contemporânea, se é artesanato, se é arte popular... Como se só arte européia tivesse valor, e como se apenas uma arte puramente intelectual fosse valorizada, ou precisasse vir de fora.

Olha o negócio é o seguinte: eu não faço tipo de pesquisa nenhuma no trabalho, mas gosto muito dos fios, sempre gostei; fui iniciada, na minha época, em trabalhos manuais no colégio. E tinha minha tia também, que me ensinava todos os pon- tos assim de bordado. Era normal na minha época aprender. Todos esses pontos de bordado, o crochê, sei fazer tudo, só não tenho paciência; nunca tive paciência de fazer, de usar o fio da maneira que ele é e fazer um. Gosto de desconstruir como é, desconstruir para construir depois. Mas como sou muito ligada a essa coisa do bordado, os crochês, e tudo que é feito na mão, assim, eu acho que têm alma. Até sei, mas não bordo nada no meu trabalho, eu me aproprio desses bordados, dessas artesanias, mesmo para construir a minha poética, sabe?...

Não é necessariamente uma pesquisa. Assim, no fundo é, não é? Porque seleciono, vou, faço, vou aos brechós para fazer uma garimpagem desses bordados que estão por lá e agora nem preciso mais porque as pessoas mandam para mim. Então procuro resgatar essa história, acho que é como se fosse um apelo mesmo, não vamos deixar isso morrer, não é?

Mariana Guimarães: Eu percebo nos seus trabalhos que, apesar de você usar muitas manualidades artesanais nos seus processos com a linguagem, você não tem nenhuma relação ou muito pouca relação 
com a técnica tradicional, é um trabalho sempre de desconstrução e de invenção; é como se eu olhasse para o seu trabalho e falasse assim: a Sonia libera o bordado da técnica, o crochê da técnica e ela faz de um jeito outro, se apropria dessa linguagem de um modo muito livre.

Sonia Gomes: Onde eu exerço a liberdade é no trabalho, sabe? Gosto dessa coisa da desconstrução. Desconstruir para depois construir da maneira que quero. Então é bem por aí, você está falando da técnica perfeitinha da coisa como ela é; acho bonito também, mas assim, não é isso que quero no meu trabalho, sabe? Então prefiro desconstruir.

Essa coisa da desconstrução talvez seja uma forma de rebeldia também do artista mesmo. Sempre tive essa rebeldia dentro de mim. Assim, comecei a fazer o que faço desconstruindo mesmo, nunca gostei, quando adolescente, de pegar uma bijuteria pronta como estava, eu sempre dava o meu toque nela; ou então era na roupa, desconstruindo. Eu desconstruindo minha roupa, aí começou a surgir o que vocês estão vendo, porque teve, foi tomando uma proporção que não dava mais para usar, para vestir, virou outra coisa, já era um apelo da arte.

O meu trabalho é mais livre mesmo, vem com descosturar, desconstruir, porque é na desconstrução que vou descobrindo as coisas, o movimento que quero dá trabalho, o trabalho é muito movimento também, vida, movimento, diversidade brasileira.

Nunca comecei também querendo ser uma grande artista, nunca passou pela minha cabeça, aconteceu naturalmente isso, que ainda está acontecendo. Então agradeço estar nesse lugar que nunca imaginei estar, porque me proponho a trabalhar com muita verdade, a verdade que eu chamo é essa: a que eu procuro e não a que eu quero. O trabalho só sai do meu ateliê quando considero que me traz aquela alegria. É como se fosse um eterno renascer, porque na obra, para a gente construir um trabalho, a gente tem muita angústia; mas quando aquilo sai assim... é uma relação que me dá uma alegria. Só considero o trabalho pronto quando ele me dá ou me traz essa alegria; se não me trouxer, é porque não está pronto ainda. Então pode até ter um prazo para entregar alguma

Mariana Guimarães; Evângelo Gasos, Sentidos do fio: diálogos com as artistas Simone Moraes e Sonia Gomes. 
obra, mas a galeria já sabe o meu processo, eles respeitam o meu tempo porque eu não deixo que o mercado exerça esse domínio sobre o meu trabalho, porque vai causar uma perda nele, em mim. Eu prefiro que seja verdadeiro.

Por que eu falo assim, o trabalho? O material é que fala o que ele quer ser. Então, se vejo uma peça, respeito muito, porque te falei que agora recebo o material, recebo as histórias das pessoas. Então tenho muito respeito por essas histórias e o material que escolhe o que é. Assim, ele dá esse trabalho porque tenho que respeitar seu momento. Ele que vai me direcionando quase, aqui não, aqui não e, tem isso mesmo... nunca fecho um trabalho... no meu ateliê tem vários assim: três, quatro trabalhos em construção assim. Pego alguma textura ou algum crochê, bordado que seja, e esse vai pra lá, um não quer ficar aqui. Assim. Às vezes até corto. Aquele não está bom aqui, outro está querendo ir para algum lugar, sabe? Depois eu fecho todos, mas nunca começo uma obra e termino, no meu ateliê tem vários..
Mariana Guimarães: Vai trabalhando em circuitos... aprendi com costureiras tradicionais que esse trabalho de unir os retaIhos chama-se fazer emenda, um nome muito singelo, seu trabalho é uma emenda muito cuidadosa de histórias, memórias, vidas...

Sonia Gomes: É uma coisa assim, na minha terra também fala emenda. Assim, até falando nisso me ocorreu agora, sempre adorei remendo, quando uma roupa rasgava, tititi [imitando som da tesoura cortando], achava aquilo lindo. Então vem daí, engraçado você puxar um fio que estava esquecido. Tem uma coisa do cerzir também, quando há aqueles puídos, vai cerzindo. Sempre gostei do avesso das coisas também, às vezes comprava uma roupa... "ah, não está bom... então fica do avesso". Vinha alguém na rua e falava "a sua roupa está do avesso" e eu falava "não..." Então essa desconstrução de tudo sempre fez parte do meu cotidiano mesmo; agora está muito em moda essa palavra ressignificar as coisas e sempre fiz isso, mas não sabia que tinha esse nome tão bonito. Então pego alguma coisa para transformar em outra, sempre fiz isso e não sabia que era arte essa coisa de res- 
significar. Então o trabalho é muito intuitivo também, sabe? Talvez essa rebeldia de não querer as coisas como elas são.

Apropriar do tecido, do bordado, da roupa que quanto mais história tiver mais importante é para mim; as pessoas podem até não ver aquela história, mas está lá para mim. Isso é importante. Essa história que o trabalho carrega, são muitas vidas, são muitas mãos e, então, é isso.

A escultura que fiz com o vestido de noiva só existe porque chegou o vestido de noiva no meu ateliê, em uma caixa, chegou do Rio de Janeiro, não conheço e nunca vi a pessoa, falou que era um vestido de quase 60 anos, entregou à outra e essa pessoa que me entregou sei que se chama Maria dos Anjos, porque perguntei o nome. Até dei o nome da obra de Maria dos Anjos, à escultura. Porque ela me deu, tipo assim "faça o que você quiser", não quis saber. Então é isso, tem umas esculturas que são o que são porque recebi aquele material. Então devo muito às pessoas que me entregam esse material, porque tem coisa ali que nem penso em fazer, só faço porque chegou o material.
Mariana Guimarães: Sonia, como é a escolha dos títulos dos seus trabalhos? São todos esculturas, ou objetos?

Sonia Gomes: Na primeira exposição que fiz, me deram um espaço em Belo Horizonte. O trabalho saiu quase como uma catarse, como se eu tivesse muita coisa a dizer, mas ninguém nunca tinha me dado voz. Então foi uma overdose, sabe? E comecei a nomear os trabalhos como torções e panos, que são aqueles mais planos, mas tudo é escultura, não é? Então tem escultura de teto, pendentes, tem escultura de chão, escultura de parede e tenho também uma série que são torções de parede, são os patuás. Eles têm esse nome porque minha avó era benzedeira e parteira. Você vê minha avó, que trabaIhava com vidas, era parteira, benzedeira, curava, tinha o poder de cura e alinhava também.

Vamos falar do fio: lembro dela, eu pequenininha e ela fazendo o ritual da cura. Era com um novelo de linha, uma agulha e a linha enfiada, ela ia benzendo a pessoa, fazendo um gesto como se estivesse retirando o mal da pessoa e levando tudo para aquele novelo de linha, com esse gesto

Mariana Guimarães; Evângelo Gasos, Sentidos do fio: diálogos com as artistas Simone Moraes e Sonia Gomes. 
de costurar. Isso é muito presente na minha memória, ela está sempre presente. Então nomeei esses trabalhos como patuás; tipo uma homenagem mesmo a ela, porque os patuás são os objetos que as pessoas usam para curar, são objetos de proteção e, mesmo eu, nunca sendo ligada a uma religião ou misticismo, nunca fui ligada a isso, respeito todas, acho todas importantes, acho que todas merecem respeito, mas não tenho isso, sabe?

Mariana Guimarães: E qual o sentido do fio para você?

Sonia Gomes: O fio é aquela coisa que a gente vê puxando, não é? Não sei porquê. Nunca pensei nisso, mas do fio, como falei lá, surge tanta coisa do fio... daquela trama, surge o tecido. Não tenho um conceito do que aquele fio é para mim, acho poético, é o que prefiro trabalhar, gosto de trabalhar com beleza e poesia; é isso que busco no mundo.

Gosto da arte contemporânea porque é livre, pode tudo. Olha, na minha exposição, no MASP, as pessoas me agradeciam, chegou uma menina perto de mim e disse: "vou trazer a minha mãe aqui, porque ela tem uma autoestima muito baixa, porque ela é costureira", entendeu? Então, trabaIhar para esse resgate da autoestima de outras pessoas, fazendo isso, costurando, bordando, fazendo crochê, é lindo. Por que se sentir menor por causa disso? É lindo também! Então acho ótima essa valorização, de estar sendo valorizado agora. É uma responsabilidade. Vejo como uma responsabilidade, encaro como uma grande, mas, assim, uma responsabilidade boa. E eu era uma pessoa que não tinha voz também, então o trabalho me deu isso. 


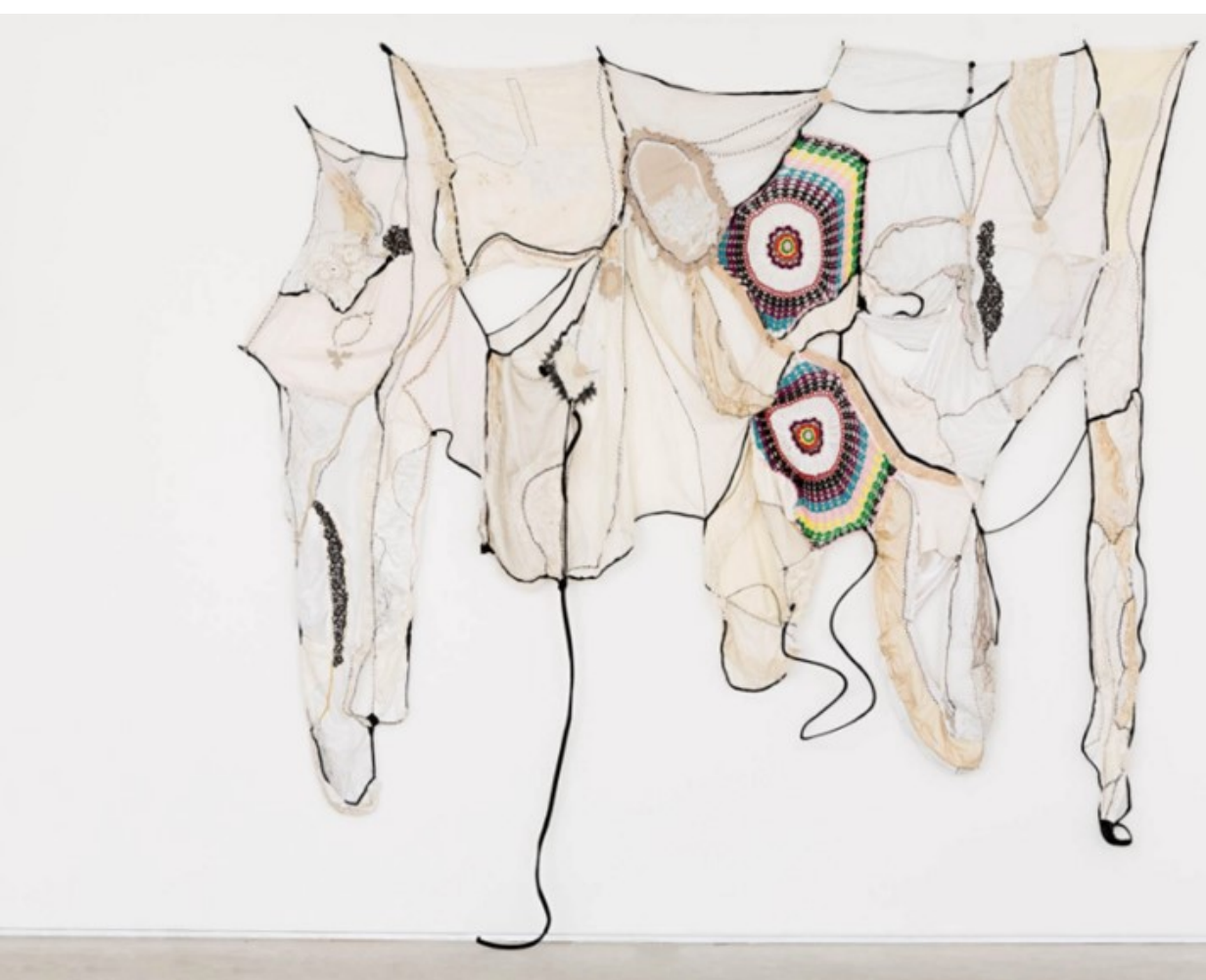




\section{Simone Moraes}

Artista visual natural de Ribeirão Preto, estado de São Paulo, vive e trabalha entre Aparecida de Goiânia (GO) e São Paulo (SP). Pesquisa vestígios de paisagens, estruturas orgânicas e resgates de uma memória pessoal através de registros, coletas e expedições. De sua pesquisa resultam formas, repetições e sobreposições de distintos materiais, desdobrando-se em objetos, intervenções, colagens, desenhos e fotografias. Graduada em Educação Artística e Artes Plásticas pela Universidade de Ribeirão Preto, UNAERP. Desde 2013 coordena a Casa Fonte, junto com os artistas Marcelo Amorim e Nino Cais, espaço dedicado à produção e a residências de arte em São Paulo. (Fonte: https://www. simonemoraes.net/bio-cv)

\section{Sonia Gomes}

Nascida em Caetanópolis, 1948, vive e trabalha em São Paulo.

Em 2018, a artista teve suas primeiras grandes mostras institucionais monográficas no Brasil, no Museu de Arte de São Paulo - MASP e no Museu de Arte Contemporânea de Niterói. Seus trabalhos também foram incluídos em mostras coletivas institucionais como a Entangled, Turner Contemporary, Margate, Reino Unido (2017); Revival, The National Museum of Women in the Arts, Washington, EUA (2017); 56 ${ }^{a} \mathrm{Bi}$ ennale di Venezia, Veneza, Itália (2015); Art \& Textiles - Fabric as Material and Concept in Modern Art, Kunstmuseum Wolfsburg, Alemanha (2013); Out of Fashion, Textile in International Contemporary Art, Kunsten - Museum of Modern Art Aalborg, Dinamarca (2013). (Fonte: https://mendes wooddm .com/pt/artist/sonia-gomes) 
